\title{
Entrepreneurship Education Grows Santri's Entrepreneurial Spirit (Evidence from Indonesia's Islamic Boarding School)
}

\author{
M. Haris Hidayatulloh ${ }^{1}$, Tika Widiastuti ${ }^{2}$, Sri Herianingrum ${ }^{2}$, and Taqiyah Dinda \\ Insani ${ }^{1}$ \\ ${ }^{1}$ Post Graduate School, Universitas Airlangga, Airlangga Street No.4 - 6, Airlangga, Gubeng, \\ Surabaya, Indonesia 60115 \\ ${ }^{2}$ Faculty of Economy and Business, Universitas Airlangga, Airlangga Street No.4 - 6, Airlangga, \\ Gubeng, Surabaya, Indonesia 60115
}

\section{Abstract}

Pesantren as the oldest educational institutions in Indonesia have an authentic method to foster the entrepreneurial spirit inside of his students. To know the implementation of entrepreneurial education, this study successfully capture to an effective system of entrepreneurship education. By using a qualitative method that uses interviews as

Corresponding Author: M. Haris Hidayatulloh tika.widiastuti@feb.unair.ac.id

Received: 10 February 2019 Accepted: 14 March 2019

Published: 28 March 2019

Publishing services provided by Knowledge E

(c) M. Haris Hidayatulloh et al. This article is distributed under the terms of the Creative Commons Attribution License, which permits unrestricted use and redistribution provided that the original author and source are credited.

Selection and Peer-review under the responsibility of the ICIEBP Conference Committee.

\section{G OPEN ACCESS}

a data collection techniques, unearthed accurate information from relevant actors in order to provide similar benefits to practitioners elsewhere. Triangulation technique has also been done so that the results of this study are robust.

Keywords: antri, Entrepreneurship, Islamic Boarding School

\section{Abstrak}

Pesantren sebagai lembaga pendidikan tertua di Indonesia memiliki metode otentik untuk menumbuhkan jiwa wirausaha di dalam diri murid-muridnya. Untuk mengetahui implementasi pendidikan kewirausahaan, penelitian ini berhasil menangkap sistem pendidikan kewirausahaan yang efektif. Dengan menggunakan metode kualitatif yang menggunakan wawancara sebagai teknik pengumpulan data, menggali informasi akurat dari para aktor yang relevan untuk memberikan manfaat yang serupa kepada praktisi di tempat lain. Teknik triangulasi juga telah dilakukan sehingga hasil penelitian ini kuat

\section{Kata kunci: Santri, Kewirausahaan, Pondok Pesantren}

\section{Introduction}

The high unemployment rate has been a problem that must be resolved by the Indonesian government. According to data from the Central Statistics Agency (BPS), the unemployment rate in Indonesia has decreased in each year and it reaches to 5.5\% in 2017, but when compared with the total labor force that reached 128.06 million people, this percentage is still quite high. Looking at this percentage would mean that there are 7.04 
million people without work (unemployed) (www.bps.go.id). The highest unemployment rate during the last 20 years occurred in 2005 after it fell to the lowest level.

Human development index (HDI) 2014 notes that Indonesia is ranked 108, which means the Human Resources (HR) Indonesia still lags behind many other developing countries. HR entrepreneurial (entrepreneur) solve the problem of limited role in employment. On the other hand, we can notice that the young generation has a little entrepreneurial spirit, as shown by the preference of scholars who want a career as an employee. This mindset comes with the culture or the existing climate in the surrounding environment. Therefore, entrepreneurship education is needed on early education levels to build the motivation of learners in entrepreneurship and to change the paradigm of preferring to become an employee.

One of the educational institutions that can provide with a solution is a boarding school. This educational model is educational boarding school dormitory, thus demanding independence. With the basic lifestyle of independence and the full supervision of the boarding school, this may establish a personality who are used to do work independently and not rely on others, and of course with a strong foundation of religious knowledge that develop spirit of obedience to Allah SWT.

Historically, the boarding school is the oldest educational institution in Indonesia. In times of an Islamic empire archipelago, Islamic boarding school stand on the centers of power and people's economy as well as being the only educational system that develops in the midst of the peoples of that time (Jauhari, 2002).

Education in Islamic boarding schools are adaptive and selective against the changing times. Nowadays, it is not uncommon that Islamic boarding schools are involve into business activities, knowing that alumni must also be prepared to face the challenges of life in the future, both social and economic. Therefore, students and alumni of Islamic boarding schools must be equipped with the skills in many areas, without eliminating the concept of education and curriculum directed by governments.

One of the boarding schools that implement entrepreneurship education is Pesantren Al Amien Prenduan. One of the few educational institutions that has competencies and interests in developing entrepreneurship education. Implementation of entrepreneurship at this institution adapted to the all level of education, making the entrepreneurship education is progressive. In addition to the provision of resources and training, this Islamic boarding school provided areas of practice as a media or means to exercise and practice for those interested in this field of entrepreneurship and business. The school is providing opportunities for students to manage several business units according to their 
ability and interest. The school also conduct a trip study of entrepreneurship (Rihlah lqtishadiyah) by visiting some distinct companies in Madura.

Several previous studies have been done related to entrepreneurship in boarding schools. Taufiq Buhari (2006) found that there are two models of economic development adopted by the Pondok Pesantren Al-Amien Prenduan. Fitri Nur Laili (2013) conducted a study that focused on the agribusiness sector with a review of the curriculum, faculty, student's age, methods, media, and assessment of learning. Irham Zaki (2017), focusing on the right educational method for building entrepreneurship. Smile Dzisi and Franklin Odoom (2014) uses the object colleges found that the portion should outweigh the theoretical practices for entrepreneurial learning. Rosni Grill, Aminul Islam, and Jocelyne Lee (2014) developed a method of boarding school education in some countries, but has yet to enter Indonesia. Shaghayegh Nikneshan, Hamed Saify, and Zohreh Sajjad (2015) explains that Islamic education entrepreneur must be in accordance with the Islamic ideology to fit. Based on these studies, it is known that there has been no indepth exploration related to how to foster entrepreneurship through entrepreneurship education for the students.

The purpose of this study is to investigate the implementation of entrepreneurship education at Pondok Pesantren Al Amien Prenduan, as a method of learning more entrepreneurship skills in Islamic boarding school. At the end of this study, it is expected to contribute to the development of education in the Islamic boarding school system, especially on the development of entrepreneurship education.

\section{Methodology}

This study uses a qualitative approach with data collection mechanism in the form of unstructured interview. Researchers prepare problems that will be asked, and thus more open interviews. Data are retrieve from key Informants among Kiai / Ustadz, active students, alumni and managers / management schools who involve in the businesses. This research applies triangulation techniques to verify the source of the data by comparing the data obtained from informants with other informants.

\section{Result and Discussion}

Education System in Pondok Pesantren Al Amien Prenduan put more emphasis on education and familiarization compared to teaching. The concept of exemplary and disciplined gain an important role in the development of the identity of students. The 
students are expected to provide benefits for himself and the public after they have graduated with science and other competencies. Not quite up there, they also had to give an example and act as role models (Uswah and Shohbah) beginning from their self. Therefore to educate and familiarization to Islamic values, science and technology are more important than just simply teaching.

Education curriculum in Pondok Pesantren Al-Amien Prenduan does not follow the national curriculum, but its curriculum is similar curriculum standards and in accordance with national curriculum standards. It can be seen from the educational system, methods of education, level of education, and the field of education. Only in Islamic boarding schools or Pondok, there are a variety of additional programs on the implementation of education tailored to the needs of students in each institution.

There are several institutions under Yayasan Pondok Pesantren Al-Amien Prenduan. Each institution has special goals and objectives in the field of education as well as tahfidzil quran that in order to get the output of students who Huffadz / Hamalatul Qur'an that implements values, teachings and the contents of the holy Al -Qur'an in everyday life. Likewise, on Tarbiyatul Muallimien Al-Islamiya (TMI) institutions, which has the goal of creating Khaira Ummah is to prepare individuals for excellence and quality in accordance with their competencies and interests, based on the teachings of Islam.

Tarbiyatul Muallimien Al-Islamiya (TMI) is one of the institutions muadalah boarding school, consisting of 48 boarding schools in Indonesia, and one of three boarding school in Madura Muadalah. Muadalah boarding school is a boarding school with its own curriculum that get equalization in accordance with the existing level. Thus, Tarbiyatul Muallimien Al-Islamiya (TMI) are implementing education-oriented that put more provisioning on basic competencies. It is not only the mastery of the subject matter alone, but scoring students are multi skilled with the philosophy of life "Meritorious, Developing, and, Independent "in the community.

In the application of basic competences oriented education, the Institute Tarbiyatul Muallimien Al-Islamiya (TMI) form the education into several programs and activities both in the field of formal education as well as in non-formal education. The study is divided in the form of basic competence (KOMDAS) consisting of Komdas $A$ and $B$. The second is Komdas options Competence (recompile) consisting of $A$ and recompile $B$.

Basic competence (Komdas) is an educational program that is compulsory for all students. A Komdas implemented in the classroom during school hours generally, and Komdas $\mathrm{B}$ implemented in a flexible time in accordance with their respective hierarchically. While the selection of competence education program are dynamic where students are required to choose from one of the fields in recompile. Recompile 
A implemented in the classroom after school hours in general (Komdas $A$ ) because education is taught in recompile $A$ is one of the field of education in Komdas $A$, in recompile $A$ students are required to deepen and must be mastered in the field of his choice compared to students of other, While recompile $B$ is an additional activity the students according to their interests, or can we call extra-curricular programs are usually held in the afternoon.

Entrepreneurship education at Tarbiyatul Mu'allimien Al-Islamiya (TMI) can be seen in a simple form, namely by providing theory and practicum. Each students need to differentiate according to the education level, respectively in this stage of entrepreneurial education. Entrepreneurship education for students who are still young (level Tsanawiyah) only to the introduction of entrepreneurship course. To facilitate those who are interested in the field of entrepreneurship is by forming a group of interest in entrepreneurship; such a group is formed with a model farm (Butani) whose management is assisted by a chosen public outsider. With a group formed in such a way, it does not put more emphasis on education, rather than to make students more than happy with the management of a business that conceptualized as land play and practice. This is due to their mentality as children who need land play and practice in mental development. Another reason why entrepreneurship education for children Tsanawiyah level is formed so as if in a concept like their superior Aliyah class, felt less effective for them as mentally not ready and still think that they doensn't need the entrepreneurial education.

Furthermore, to the level of implementation Aliyah differentiated for grade level students. For the students of fourth grade they get on the observation of the upperclassmen $\mathrm{V}$ (caretaker KOPWIRA) and ustadz involved in the field of entrepreneurship to be a cadre of managers of the business units boarding school in such period. Thereafter, search and monitoring is also adjustable in their interest, in other words, students who interested do not need to appointed, are enrolled. Since then they began to be included in managing such units under the guidance of seniors $V$ as caretaker Kopwira.

Entrepreneurship education to students in class $\mathrm{V}$ more towards giving the mandate to manage the business unit Boarding School, the mandate is given to those who already cadred since Class IV, but do not rule out the possibility for those who are not cadres, those who have the competence in this field on monitoring of consultant cleric Kopwira or other ustadzs recommend them. Students who are competent to offer and if they are interested they will be mandated to manage the business unit even without previous cadre. Before the handover to manage business units fully they will be given a 
theory of entrepreneurship, which is formed by Leadership Training and Management program (PKM) for four days,

The latter is an education to the sixth grade. For students of class VI is no longer divided according to their interests and potential of each of them. When class VI each students will join the program devoted to them ie Niha'ie Program (Final grade) where the program contains all fields of competence and wajid followed by all students, among other things is the field of propaganda, education, linguistic field, the field of entrepreneurship, etc. are important areas to prepare them directly involved in public life. Such programs are given so that at least they are understanding the correct basics of each of these fields.

Shape or concept of entrepreneurship education in the same program with the niha'ie on entrepreneurship education in the fifth grade, is just a different application. Providing material (theory) entrepreneurial held for two weeks and to practice them is programmed in the form of field studies (Rihlah lqtishadiyah) is by visiting some companies in Madura. The trip aims to see directly the process of managing, transform, and get the motivation as well as direction from the employer to the empirical study corresponding respective experiences companies, so that students can learn more from the experiences of the growing interest especially if they are to grow their interest in entrepreneurship.

One of the goals of entrepreneurship education boarding school is developing entrepreneurial spirit of students as a preparation for life in the future. Efforts are made to the provision of entrepreneurial education tailored to the education of students. In the practice of entrepreneurship with the management of a business unit of the boarding school, students are given the power and responsibility for decision-making and development business unit. The cleric as a builder just keep an eye on them and make improvements if there are errors but not to intervene in their inputs in decisions, actually this form is not only applicable in the field of entrepreneurship but also be applied to other fields. By giving the authority and responsibility for the business unit, students are required to be more active and creative in the development of the interest and the trust given. Practice in the field is more beneficial compared to prioritize education in administration theories. Experiences gained when managing business unit with its difficulties and gains can be used as a glass comparison to those in real life that is in the future. Thus, they will get used to conduct and manage any activity (enterprises).

To expand the theory of entrepreneurship education, an effort to foster an entrepreneurial spirit Tarbiyatul Institute Mu'allimien Al-Islamiya (TMI) is to put more emphasis on mentoring and coaching students. For the formation of a consultant on each group consist of asatidz. One form of mentoring and coaching are the monitoring 
and weekly evaluation, thus consultant can easily monitor the progress of their students on a field that is mandated. In addition to the periodic evaluation, consultant can increase their closeness and develop good coordination in work or in everyday life, the emotional closeness can help the education process goes well.

Implementation of entrepreneurship education by Suherman (2010: 19) should start from educating, training, mentoring and coaching. Along with the process of consultation, evaluation is conducted especially for things pragmatically in order to complete the learning process directed at the cognitive, affective, and psychomotor skills. Consultation has a very important role in the educational process. The TMI establishes consultants in each field consisting of ustadzs competent in the field of consulting as a means provided for students, every time they require consultation and implement common routines every week in the form of evaluation.

\section{Conclussion}

The curriculum used by the Prenduan Al-Amien Islamic Boarding School is the curriculum of the boarding school itself, which has the same standards as the national curriculum standards. Entrepreneurship education is one of the many fields of education that exist. The implementation of entrepreneurship education is adjusted to the level of Santri education on the grounds of harmony between needs and the level of mental ability of students. Entrepreneurship education is given in the form of theory and practice of entrepreneurship with programs of education, training, guidance, and coaching. The institution forms consultants in the field of entrepreneurship that are responsible for supervision and as a means of consultation for Santri at any time needed, and with a routine consultation agenda that is formed with an evaluation model. Such concept of education is considered effective in developing the cognitive skills and psychomotor domains of Santri as they learn and practice by exploring the fields of interest. Santris have developed the provision of competence with the basics of strong Islamic law to be applied in life and in the life of hereafters.

\section{References}

[1] Bakar, Rosni, Aminul Islam, dan Jocelyne Lee. 2014. Entrepreneurship Education: Experiences In Selected Countries. Journal Internasional Studies: Vol. 8, No.1 Tahun 2014. 
[2] Dzisi, Smile Dan Franklin Odoom. 2014. Entrepreneurship Education And Training In Higher Educational Institutions In Ghana. Springer Science Business Media. LLC 2014.

[3] Gaddam, S. 2008. Identifying the Relationship Between Behaviora Motives and Entrepreneurial Intentions: An Empirical Study Based Participations of Business Management Students. The Icfaian Journal of Management Research. 7, 35-5

[4] Laili, Fitri Nur. 2013. Pembelajaran Kewirausahaan Di Pesantren Wirausaha Agrobisnis Abdurahman Bin 'Auf Klaten. Tesis, tidak diterbitkan. Universitas Sebelas Maret Yogyakarta.

[5] Moleong, Lexy. J. 2000. Metodologi Penelitian Kualitatif. Bandung: PT. Remaja Rosdakarya.

[6] Nikneshan, Shaghayegh, Hamed Saify, dan Zohreh Sajjad. 2015. Entrepreneurship Education From The Viewpoint Of Islam. Meditrranean Journal Of Social Sciences MCSER Publishing, Rome-Italy. Vol. 6, No. 5 S2, September 2015.

[7] Widiatnoto, Erfikas. 2008. Manajemen Pengembangan Kewirausahaan siswa SMK 4 Yogyakarta. Tesis magister, tidak diterbitkan. Universitas Negeri Yogyakarta.

[8] Yin, Robert K. 2013. Studi Kasus: Desain Dan Metode. Jakarta: Rajawali Press.

[9] Zhao, H., Seibert, S.E., \& Hills, G.E. 2005. The Mediating Role of Self Efficacy in the Development of Entrepreneurial Intention. Journal of Applied Psychology, 90, 1265-1271.

[10] http://al-amien.ac.id.

[11] http://kemenag.go.id.

[12] www.bps.go.id. 